Table 1. Sporulation and Growth of Yeast after Three Days UNDeE SEVERAL NUTHitional CoNDitions

Substances present

0* Stage of sporogenesis

$\begin{array}{ccccc}9.3 & 1 & 2 & 3 & 4 \\ 97 \cdot 3 & 3 \cdot 0 & 0 \cdot 1 & 0 \cdot 0 & 0 \cdot 0\end{array}$

$\begin{array}{rrrrr}97 \cdot 3 & 3 \cdot 0 & 0 \cdot 1 & 0 \cdot 0 & 0 \cdot 0 \\ 26.9 & 10 \cdot 1 & 0 \cdot 7 & 5 \cdot 0 & 57 \cdot 3\end{array}$

$97 \cdot 2-3.0-0.0-0.0-0.0$

$\begin{array}{lllll}32.5 & 12.6 & 0.9 & 7.0 & \mathbf{4 7 . 4}\end{array}$

Cell increase

1. Buffer onl

3alts-vitamin

Acetate, salts-

vitamins

Ammonium

suiphate

Acetate, a

molphate

7. Salts-vitamins,

ammonium

sulphate

8. Acetate, salts-
vitamins,

sulphate

96.5

$0 \cdot 1$

$59 \cdot 5$

$\begin{array}{llll}3.1 & 0.1 & 0.1 & 0.1\end{array}$

$0 \cdot$

0.5

$1 \cdot 6$

$0 \cdot 2$

$\begin{array}{lllll}96.5 & 3.4 & 0.0 & 0.1 & 0.0\end{array}$

$6 \cdot 3$

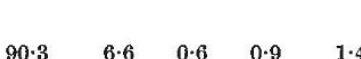

$0 \cdot 8$

* These figures give the percentage of cells in successive stages of sporogenesis. 0, Nucleus vegetative; 1, nucleus appearing enlarged, more or less diffuse; 2, two nuclei in the cell, or else first nuclear division occurring; 4 , spore walls formed around some or all of the nuclei.

Comparing Nos. 4 and 8 in Table 1, the latter combination provided a complete medium which supported active vegetative growth, and few cells sporulated. But omission of ammonium sulphate, as in No. 4, caused more than half the cells to undergo meiosis. Thus the presence or absence of a simple inorganic compound was a primary factor in determining whether the nuclei underwent equational or reductional division.

The key role of assimilable nitrogen in this respect is shown by the fact that ammonium carbonate and certain amino-acids also serve as nitrogen sources for growth (thus promoting mitosis) and inhibit meiosis ${ }^{8}$. It should be mentioned, however, that under conditions where yeast sporulation occurs in the absence of an exogenous carbon source, ammonium sulphate does not inhibit sporulation ${ }^{6}$, and this indicates that both carbon and nitrogen sources participate in the inhibition.

This work was supported by a research grant from the Ontario Research Foundation.

Department of Biology,

J. J. Miller

Hamilton College,

McMaster University,

Hamilton, Ontario.

${ }^{1}$ Pontefract, R. D., and Miller, J. J., Canad. J. Microbiology, 8, 573 (1962).

${ }^{2}$ Winge, 6., C.R. Trav. Lab. Carlsberg, Sér. physiol., 21, 77 (1935).

${ }^{2}$ Lindegren, C. C., The Yeast Cell, Its Genetics and Cytology (Educational Publishers, Inc., St. Louis, Miss., 1949).

4 Miller, J. J., Wallerstein Lab. Comm. 22 (79), 267 (1959).

${ }^{5}$ Wickerham, L., U.S. Dept. Agric, Tech. Bull. No. 1029 (1951).

"Miller, J. J., Canad. J. Microbiol. (in the press).

" Miller, J. J., Stain Tech., 36, 289 (1961).

$\checkmark$ Miller, J. J. (unpublished results).

\section{A Large Chromosome in the Laminarian Nucleus}

A cytological examination of female gametophytes of Laminaria digitata (Huds.) Lamour, L. saccharina (L) Lamour, L. hyperborea (Gunn.) Fosl., L. ochroleuca de la Pylaie., grown in culture has revealed a likely haploid chromosome number of 31. This agrees with earlier work $^{1}$ on Laminaria spp. and with work ${ }^{2}$ on Nereocystis luetkeana (Mert.) Post and Rupr.

The chromosomes vary considerably in size and range between approximately $0 \cdot 4 \mu$ and $1 \cdot 7 \mu$ across their greatest dimension. It is found that in any dividing female nucleus at metaphase there are at least two very small chromosomes (Fig. 1, b), and there is usually one chromosome which is conspicuously larger than the others (Fig. 1, a) while the rest are intermediate but not uniform in size. As metaphase figures in young cultured sporophytes usually show only one larger chromosome it would not appear that the male gametophyte contributes a chromosome of that size. However, work is being carried out to ascertain whether the much smaller dividing nuclei of the male gametophytes possess this larger chromosome, and.

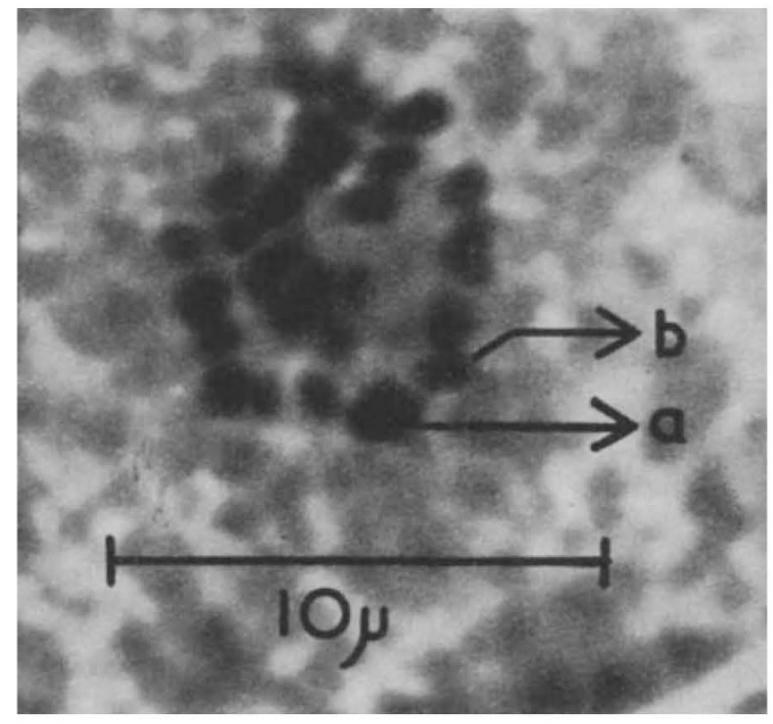

Fig. 1. Large chromosome (a) and small chromosomes (b) in Laminaria

also to find out how the larger chromosome from the female nucleus pairs at meiosis in the young sporangium.

Work carried out so far on Alaria esculenta (L.) Grov. Chorda filum (L.) Stackh. and Saccorhiza polyschides (Lightf.) Batt., though not yet complete, indicates their haploid chromosome numbers to be in the region of 30 also, and observations on cultured female gametophytes of $S$. polyschides has shown the invariable presence of a very large chromosome which is absent in the male gametophytes. It is interesting to note that Allen', who has established similar chromosome differences correlated with sex differences in the moss Sphaerocarpos, foresaw the possibility that other plants likely to show this phenomenon would perhaps include "some of the dioecious algae".

Chromosome size differences were noted in Pterygophora californica ${ }^{4}$ Rupr. and Egregia menziesii ${ }^{5}$ (Turn.) Aresch. and the investigators classified them into groups according to size. No other reference can be found to such grouping of chromosomes, or to the presence of a very large chromosome in the nuclei of members of the Laminariales

Marine Science Laboratories,

$$
\text { L. V. Evans }
$$

Menai Bridge,

Anglesey.

1 Kemp, L., and Cole, K., Canad. J. Bot., 39, 1711 (1961).

${ }^{2}$ Naylor, M., Ann. Bot., 20, 341 (1956).

${ }^{3}$ Allen, C. E., Proc. Amer. Phil. Soc., 58, 289 (1919).

4 McKay, H. H., Univ. Calif. Pub. Bot., 17, 111 (1933).

${ }^{5}$ Meyers, M. E., Cniv. Calif. Pub. Bot., 14, 225 (1928).

\section{GENETICS}

\section{Interaction of Insulin and Chlorpromazine in Teratogenesis}

IT has been shown that treatment of chicken embryos with insulin will produce malformations of quite different kinds according to the developmental stage at which the hormone is administered. During the earliest period of incubation rumplessness is the typical insulin-induced defect, that is, a partial or complete suppression of the tail skeleton and its related soft tissues ${ }^{1-3}$. When, however, insulin is injected after 4 or 5 days of incubation the tail structures remain intact, but the embryos are likely (incidence and severity always depending on dosage) to have disproportionately short legs (micromelia) and abnormalities of the facial skeleton, most commonly expressed as a shortening of the upper beak ${ }^{4}$. During the 